\title{
Pruning Southern Highbush Blueberry in Florida ${ }^{1}$
}

\author{
Douglas A. Phillips and Jeffrey G. Williamson²
}

Pruning is an essential part of blueberry production and is used to help establish new plantings; promote postharvest growth of new foliage and fruiting wood; balance vegetative and reproductive growth; reduce disease and certain insect pressure; assist in harvesting efficiency; and promote new cane growth and plant longevity. The following is a discussion of pruning practices on southern highbush blueberry in Florida.

\section{New Plant Establishment}

Growers may consider removing $1 / 3$ to $1 / 2$ of the top of young blueberry plants when they are planted in the field if they have become long, leggy, and rootbound in their containers. This will help to balance the top of the plant with the root system until root growth can support a larger plant top. Weak or twiggy growth can be removed at the same time. Historically it has been common to remove flower buds from young plants in the first and sometimes the second year after planting to encourage foliage and canopy growth. However, particularly in the evergreen system on vigorous cultivars, some growers have been harvesting young blueberry plants within 12 to 18 months after planting, so removing buds is not recommended in every situation.

Many growers interested in machine harvesting have begun to place cardboard milk or juice cartons over new plantings during the first two years to train the plant to have a narrower crown, which can help reduce ground loss during harvesting (Figures 1 and 2). The cartons may also protect young stems from herbicide damage, and (in certain cultivars) reduce the need for pruning of suckers emerging from the bottom of the plant. However, once the cartons are removed, continued pruning at the base of the plant is needed to maintain a narrow crown.

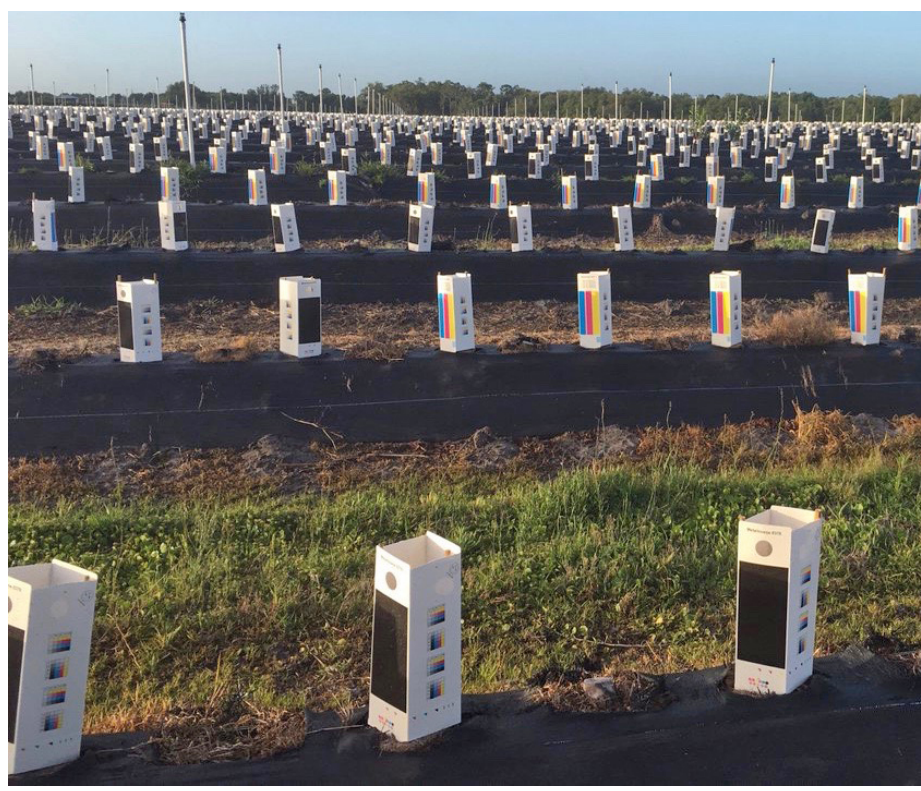

Figure 1. Cardboard cartons on young blueberry plants.

Credits: D. Phillips, UF/IFAS

\section{Postharvest Hedging}

Postharvest hedging or topping is typically done shortly after fruit harvesting is finished, usually in early June. Delaying hedging until mid-to-late summer may negatively impact floral bud differentiation and yield. Many growers use mechanical hedgers or sickle bars mounted on tractors to reduce plant height to around $40-48$ inches while also

1. This document is HS1359, one of a series of the Horticultural Sciences Department, UF/IFAS Extension. Original publication date March 2020. Visit the EDIS website at https://edis.ifas.ufl.edu for the currently supported version of this publication.

2. Douglas A. Phillips, blueberry Extension coordinator, and Jeffrey G. Williamson, professor, Horticultural Sciences Department; UF/IFAS Extension, Gainesville, FL 32611.

The Institute of Food and Agricultural Sciences (IFAS) is an Equal Opportunity Institution authorized to provide research, educational information and other services

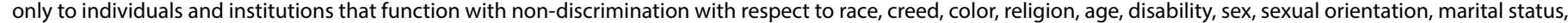

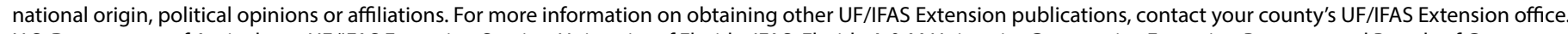
U.S. Department of Agriculture, UF/IFAS Extension Service, University of Florida, IFAS, Florida A \& M University Cooperative Extension Program, and Boards of County Commissioners Cooperating. Nick T. Place, dean for UF/IFAS Extension. 
trimming the sides of the plant so they do not overhang into the row middles. This method significantly reduces the cost of hedging compared to hand pruning. Growers on smaller farms may use handheld gas-powered trimmers. While many growers hedge straight across the top of the plant (Figure 3), some growers prefer a "rooftop" cut angled 45-55 degrees up to a point in the center of the plant canopy (Figure 4). Hedging promotes growth of the plant canopy and new fruiting wood; it is essential to vigorous, healthy growth throughout the summer and to maintaining consistent yield (Figure 5). Hedging also allows greater sunlight penetration into the canopy, possibly increasing the number of flower buds. While most southern highbush cultivars respond well to this pruning, it should be noted that 'Chickadee' does not. Several growers have reported that 'Chickadee' can struggle to achieve significant regrowth following hedging, especially after the plant is around 2 years old. These growers have adopted the practice of lightly tipping 'Chickadee' following harvest instead of the typical hedging.

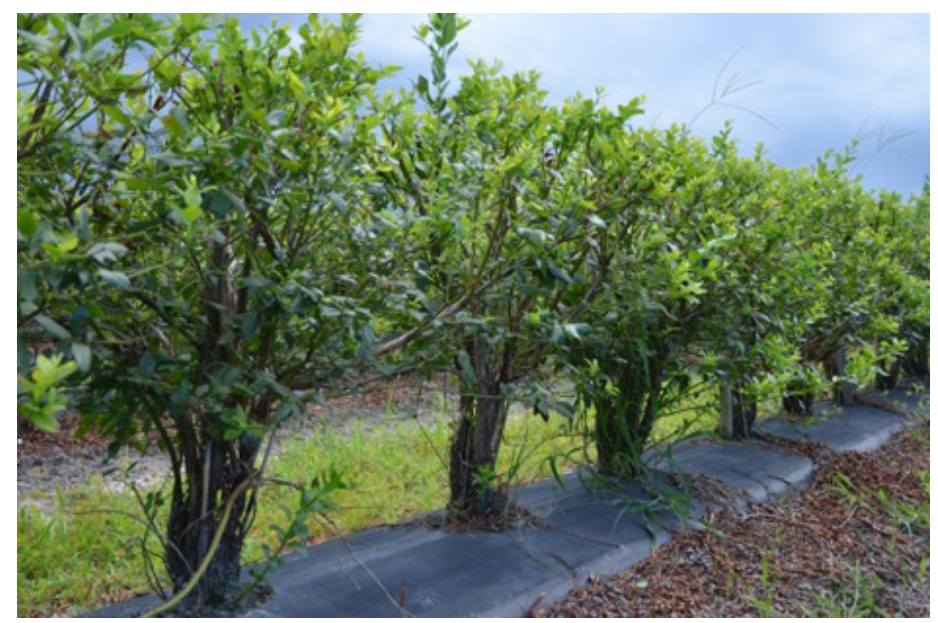

Figure 2. 'Farthing' plant previously trained to a narrow crown with cartons.

Credits: J. Williamson, UF/IFAS

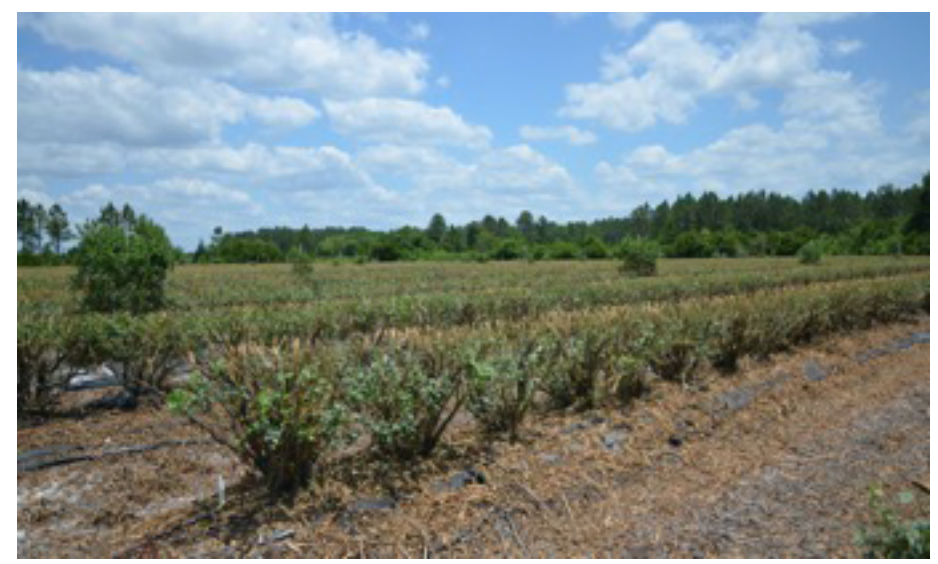

Figure 3. Blueberry field following mechanical hedging and topping done soon after completion of the harvest season.

Credits: J. Williamson, UF/IFAS
In addition to promoting vegetative growth, hedging can help reduce disease pressure by removing inoculum (e.g., rust and Septoria) from the field. It will also open up the plant canopy to allow for better air flow (promoting faster foliage drying and therefore less fungal disease) and better coverage when spraying fungicides and insecticides. Hedging can also remove damaging insects from the plant's top growth, including blueberry bud mites and wax scale. Because hedging can create an entry point for disease pathogens such as Botryosphaeria (stem blight), it is important to spray a fungicide, such as captan, immediately after hedging to minimize the opportunity for plant infection (Figure 6).

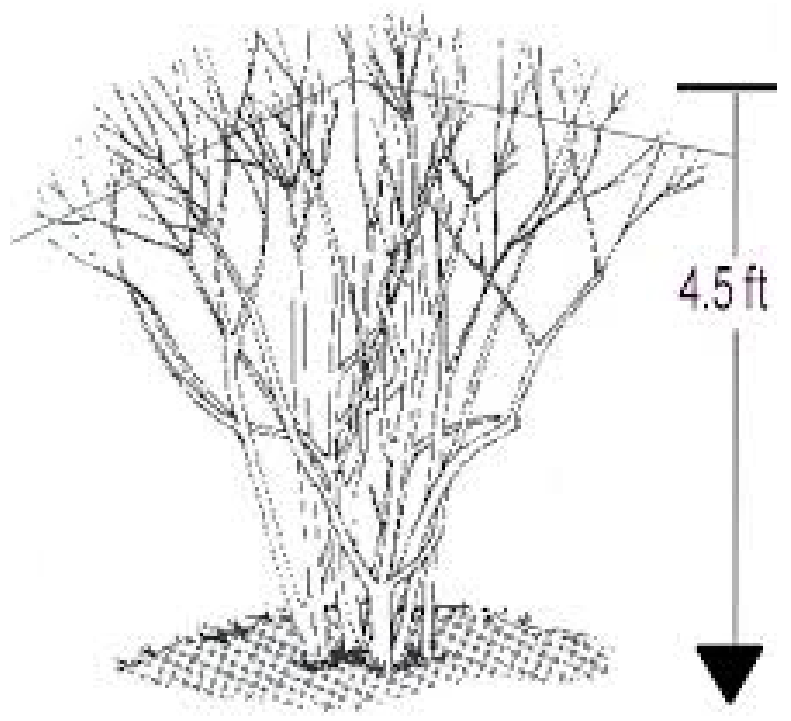

Figure 4. Summer blueberry pruning using the "rooftop" method. Credits: UF/IFAS

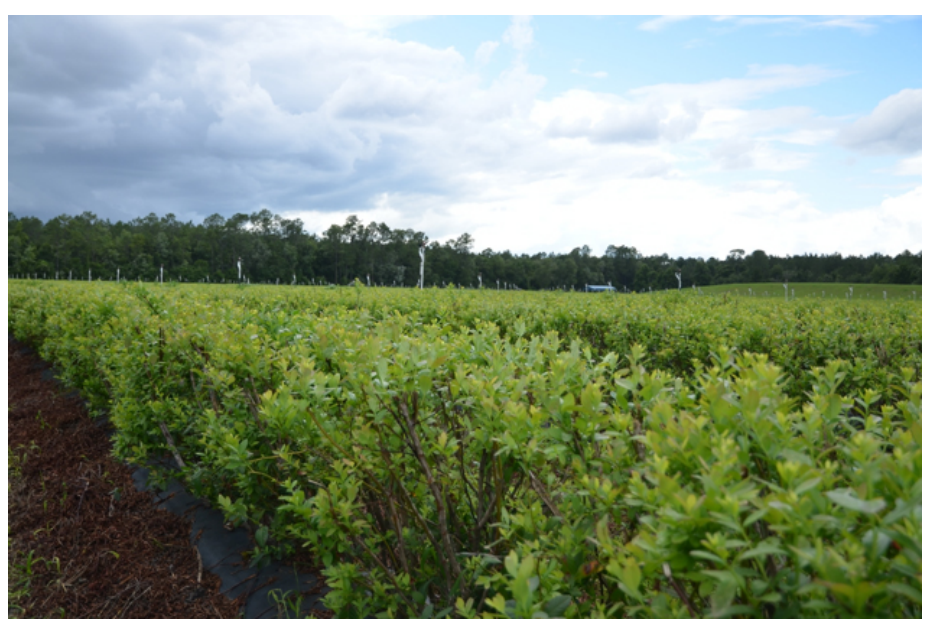

Figure 5. Regrowth following summer hedging and topping (midJune).

Credits: J. Williamson, UF/IFAS 


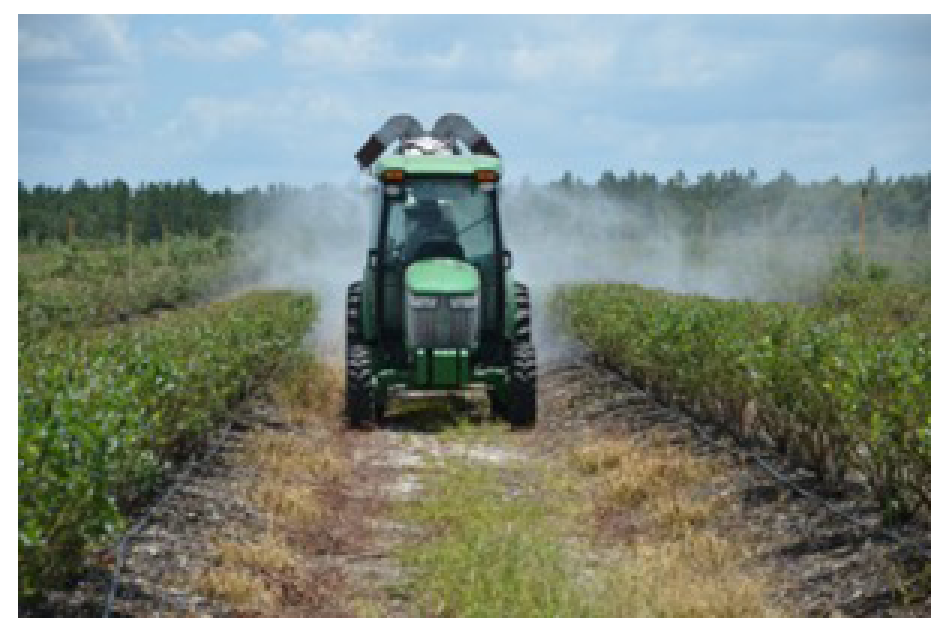

Figure 6. Fungicide application immediately following summer pruning.

Credits: J. Williamson, UF/IFAS

\section{Cane-Renewal Pruning}

After a blueberry plant is around 4 to 5 years old, canerenewal pruning must be performed annually to stimulate the growth of new canes and open the plant canopy for better airflow and sunlight penetration. This can help lengthen the productive life of the plant, encourage plant vigor, and reduce fruit load if needed to promote earlier ripening and larger fruit. Around $1 / 4$ of the oldest canes should be removed each year by cutting them back to the plant crown or to a strong lateral point. Dead, weak, crossing, or low-spreading branches can also be removed at this time. Cane-renewal pruning is typically done during December or January in Florida, when plants in the deciduous system are dormant, although it can also be performed at the same time as summer hedging.

\section{Rejuvenation Pruning}

If blueberry plants have not been pruned for several years and are unproductive, it may be possible to rejuvenate the plants through aggressive pruning, depending on the cultivar and overall plant health. With this method, all the plant's canes are hedged back to 1-2 feet, either in early summer or during winter when deciduous plants are dormant. This will significantly reduce the yield on these plants for the next one or two seasons. If growers have this situation and are evaluating this type of pruning, they should consider using it on only a portion of their field in a year to maintain some level of production during this process.

\section{References}

Kovaleski, A., J. Williamson, and B. Casamali. 2015. "Effects of Timing and Intensity of Summer Pruning on Vegetative Traits of Two Southern Highbush Blueberry Cultivars." HortScience 50 (1): 68-73.

Lee, S., J. Cho, M. Shin, S. Oh, H. Kim, and J. Kim. 2015. "Effects of Summer Pruning Combined with Winter Pruning on Bush Growth, Yields, and Fruit Quality of 'Misty' Southern Highbush Blueberry for Two Years after Planting." Hortic. Environ. Biotechnol. 56 (6): 740-748.

Retamales, J. B., and J. F. Hancock. 2012. Blueberries. CAB International, Cambridge, MA.

Williamson, J., F. Davie, and P. Lyrene. 2004. Pruning Blueberry Plants in Florida. HS985. Gainesville: University of Florida Institute of Food and Agricultural Sciences. https://ufdcimages.uflib.ufl.edu/IR/00/00/26/82/00001/ HS22300.pdf 